\title{
ALLOMETRIC MODEL DEVELOPMENT IN LODGEPOLE PINE FORESTS OF THE GREATER YELLOWSTONE ECOSYSTEM
}

\author{
DANIEL B. TINKER — RICK ARCANO DEPARTMENT OF BOTANY \\ UNIVERSITY OF WYOMING — LARAMIE
}

\section{$\downarrow \quad$ INTRODUCTION}

Allometric equations for estimating aboveand belowground biomass of lodgepole pine have been developed in Alberta, Canada, southeastern British Columbia, southeastern WY, and in Washington and Oregon (Johnstone 1971; Comeau and Kimmins 1989; Pearson et al. 1984; Gholz et al. 1979, respectively). More recently, allometric equations for young lodgepole pine saplings have also been developed in Yellowstone National Park (YNP) for aboveground biomass by Turner et al. (2004), and for belowground biomass by Litton et al. (2003). However, because of variability in latitude, growing conditions, substrate and climate, existing equations that predict biomass for mature lodgepole pine trees are not appropriate for use in the Greater Yellowstone Ecosystem (GYE), and new allometric equations specific for the GYE are needed. In this study, we will develop new allometric equations for predicting above- and belowground biomass in mature lodgepole pine forests of the GYE.

The specific objective of this study was to develop allometric models for predicting above and belowground biomass of mature lodgepole pine trees in the GYE, and determine how these equations differ with stand density and age.

\section{$\downarrow \quad$ MATERIALS AND METHODS}

\section{STUDY AREA}

The study area was within the GYE on the Caribou-Targhee National Forest (CTNF) bordering YNP. The dominant forest type is lodgepole pine forest, which occurs at middle elevations, but Spruce/ Fir (Picea engelmanii /Abies lasiocarpa) forests occur at higher elevations and Douglas-fir (Pseudotsuga menziesii) forests occur at lower elevations.

\section{Field and Lab Methods}

Allometric equations were developed in three lodgepole pine stands on the CTNF that represented two age classes and two density classes. In the young (64 years old) age class, two stands of different densities were examined; one dense (YD) $(2,452$ trees/ha) and the other sparse (YS) (725 trees $\left.\mathrm{ha}^{-1}\right)$. Because densities of lodgepole pine stands tend to converge as they get older (Kashian et al. 2005), a single sparse $\left(674\right.$ trees $\left.\mathrm{ha}^{-1}\right)$ stand was sampled in the older age class (OS) (164 years old).

Although sites differed in density and age, they were located on similar soils. The Koffgo soil series consists of loamy-skeletal, mixed, superactive Vitrandic Cryochrepts. All sites were located at least $50 \mathrm{~m}$ from the road to facilitate equipment hauling and to avoid road influences. 
All aboveground tree biomass totaling 46 trees was harvested within the three stands, and 24 root systems were excavated to develop allometric equations where easily obtained morphological parameters, such as diameter at breast height, were tested as predictors of above and belowground tree components. Fourteen trees were harvested in the YD stand and 15 trees were harvested in the YS stand; 17 were harvested in the OS stand. For belowground components, 5 root systems were excavated in both the YS and OS stands due to logistical difficulties associated with large root systems, while 14 root systems were harvested in the YD stand.

Prior to harvest, DBH (diameter at breast height, $1.37 \mathrm{~m}$ ) and crown width were recorded. After felling of the tree, total height and height to crown base were measured. Crown base was defined as the point along the bole at the bottom of roughly $90 \%$ of the crown mass, and crown length was calculated as:

$$
C L=H-H C B
$$

where $C L=$ crown length, $H=$ total tree height, and $H C B=$ height to the base of the live crown.

\section{Aboveground Components}

\section{Tree Bole}

Each bole was harvested and all branches were removed. For each bole, a disc was always taken at $\mathrm{DBH}$ and at $90 \%$ of crown base. Each bole section was weighed separately using a digital hanging scale (Salter-Brecknell). Discs were dried to a constant weight at $70^{\circ} \mathrm{C}$ in the lab to determine moisture content, and the dry: wet weight ratio for each disc was applied to determine dry weight of the entire bole section. For each DBH and crown base subsample, the following measurements were taken for determining sapwood area: phloem + bark thickness, total diameter, and heartwood diameter. Sapwood diameter can be determined by subtracting the diameter of phloem + bark and heartwood diameter from total diameter.

\section{Branches}

Branches were cut flush with the tree bole and were separated from foliage at $6.4 \mathrm{~mm}$ in diameter. Thus, branches consisted of all shoots minus the tree bole that were greater than $6.4 \mathrm{~mm}$ in diameter, because biomass smaller than $6.4 \mathrm{~mm}$ are likely to be consumed by fire (Despain 1990), allowing for post-fire estimates of branch biomass, independent of fine fuels that were likely to be consumed the fire. A subsample of approximately
4.0 L was taken to determine moisture content for dry weight for each tree, where it was then dried in the lab.

\section{Fine Fuels}

The fine fuels component was considered to be all needles and associated twigs less than $6.4 \mathrm{~mm}$ in diameter. The fine fuels component was maintained in separate piles of lower, middle, and upper crown sections for each tree, since foliage moisture contents were likely to vary with crown height (Brown 1978). A random subsample approximating the size of approximately $4.0 \mathrm{~L}$ volume was taken from each crown section to determine moisture content. The fine fuels subsamples were then weighed to obtain wet weight.

\section{Belowground Components}

For each tree, the entire coarse root system $(>10 \mathrm{~mm}$ diameter) was excavated with a backhoe or come-a-long. After excavation, the root system was divided into four size classes: root crown (i.e. the massive structure directly beneath the tree bole), lateral roots $>50 \mathrm{~mm}$ in diameter, lateral roots 25 $50 \mathrm{~mm}$ in diameter, and lateral roots $10-25 \mathrm{~mm}$ in diameter. Total weight of each root size class was weighed using a digital hanging scale. Subsamples were taken and weighed to determine moisture content for dry weight of each size class.

\section{Statistical Analyses and equation development}

All allometric models were developed with SPSS 13.0 (SPSS Inc. 2005). Models for each tree component (Table 1) were developed for the three individual stands, for all sites combined, and were also pooled by density and age.

\section{Model Comparison}

\section{Density and Age}

To determine whether allometric models differed between stands of varying densities and ages, models pooled by density and age, were compared using the extra sum of squares analysis for nested models (Bates and Watts 1988). In addition, equations for total aboveground biomass and coarse root biomass were used to predict biomass in a different stand from where they were developed. For instance, pooled equations from the two young stands were used to predict above and belowground biomass in the older stand, to determine the degree of error produced from using an inappropriate model. 


\begin{tabular}{|c|c|c|c|c|c|c|c|c|c|}
\hline \multicolumn{10}{|c|}{ Non Linear Power Functions $\left(y=a x^{b}\right.$, or $\left.y=a x^{b} x_{2}^{c}\right)$} \\
\hline$(\mathrm{Y})$ & $(\mathrm{X})$ & $\operatorname{Site}(s)$ & $\begin{array}{c}\text { DBH range } \\
(\mathrm{cm})\end{array}$ & $n$ & $a$ & $b$ & $c$ & $R^{2}$ & MSE \\
\hline & Volume** & All Sites & $5.4-33.3$ & 46 & 0.005 & 0.793 & - & 0.95 & 679.6 \\
\hline Total & - & Old, Sparse & $11.3-33.3$ & 17 & 0.003 & 0.817 & - & 0.94 & 758.4 \\
\hline Abovegroun & - & Young, Dense & $5.4-15.6$ & 14 & 0.00004 & 1.155 & - & 0.84 & 109.9 \\
\hline \multirow{3}{*}{ d Biomass } & - & Young, Sparse & $11.7-25.0$ & 15 & 0.0004 & 1.001 & - & 0.92 & 445.2 \\
\hline & - & 2 Young Stands & $5.4-25.0$ & 29 & 0.0001 & 1.088 & - & 0.95 & 289.4 \\
\hline & - & 2 Sparse Stands & $11.3-33.3$ & 32 & 0.010 & 0.741 & - & 0.94 & 810.0 \\
\hline \multirow{6}{*}{$\begin{array}{l}\text { Total Coarse } \\
\text { Root } \\
\text { Biomass } \\
(>10 \mathrm{~mm})\end{array}$} & Basal Area $\left(\mathrm{cm}^{2}\right)$ & All Sites & $5.4-32.0$ & 24 & 0.028 & 1.139 & - & 0.95 & 11.8 \\
\hline & - & Old, Sparse & $11.3-32.0$ & 5 & 0.188 & 0.845 & - & 0.93 & 36.4 \\
\hline & - & Young, Dense & $5.4-15.6$ & 14 & 0.005 & 1.467 & - & 0.98 & 0.3 \\
\hline & - & Young, Sparse & $12.7-24.3$ & 5 & 0.002 & 1.579 & - & 0.95 & 8.3 \\
\hline & - & 2 Young Stands & $5.4-24.3$ & 19 & 0.006 & 1.406 & - & 0.97 & 2.0 \\
\hline & - & 2 Sparse Stands & $11.3-32.0$ & 10 & 29.939 & -0.179 & - & 0.99 & 5.8 \\
\hline \multirow{6}{*}{$\begin{array}{l}\text { Root Crown } \\
\text { Biomass }\end{array}$} & Basal Area $\left(\mathrm{cm}^{2}\right)$ & All Sites & $5.4-32.0$ & 24 & 0.020 & 1.109 & - & 0.84 & 13.6 \\
\hline & - & Old, Sparse & $11.3-32.0$ & 5 & 0.224 & 0.745 & - & 0.71 & 65.5 \\
\hline & - & Young, Dense & $5.4-15.6$ & 14 & 0.007 & 1.267 & - & 0.93 & 0.2 \\
\hline & - & Young, Sparse & $12.7-24.3$ & 5 & 0.007 & 1.284 & - & 0.89 & 5.3 \\
\hline & - & 2 Young Stands & $5.4-24.3$ & 19 & 0.006 & 1.304 & - & 0.95 & 1.1 \\
\hline & - & 2 Sparse Stands & $11.3-32.0$ & 10 & 0.050 & 0.968 & - & 0.73 & 33.8 \\
\hline \multirow{6}{*}{$\begin{array}{l}\text { Lateral Root } \\
\text { Biomass } \\
(>10 \mathrm{~mm})\end{array}$} & Basal Area $\left(\mathrm{cm}^{2}\right)$ & All Sites & $5.4-32.0$ & 24 & 0.008 & 1.193 & - & 0.94 & 2.1 \\
\hline & - & Old, Sparse & $11.3-32.0$ & 5 & 0.010 & 1.146 & - & 0.94 & 4.8 \\
\hline & - & Young, Dense & $5.4-15.6$ & 14 & 0.0004 & 1.738 & - & 0.91 & 0.2 \\
\hline & - & Young, Sparse & $12.7-24.3$ & 5 & 0.00003 & 2.153 & - & 0.94 & 2.6 \\
\hline & - & 2 Young Stands & $5.4-24.3$ & 19 & 0.001 & 1.564 & - & 0.94 & 1.0 \\
\hline & - & 2 Sparse Stands & $11.3-32.0$ & 10 & 0.011 & 1.147 & - & 0.89 & 5.2 \\
\hline \multirow[t]{6}{*}{ Branches } & $\begin{array}{l}\text { Basal Area }\left(\mathrm{cm}^{2}\right), \\
\text { Crown Length }(\mathrm{m})\end{array}$ & All Sites & $5.4-33.3$ & 46 & 0.022 & 0.683 & 1.276 & 0.69 & 69.3 \\
\hline & - & Old, Sparse & $11.3-33.3$ & 17 & 0.003 & 1.136 & 0.850 & 0.86 & 21.6 \\
\hline & Basal Area $\left(\mathrm{cm}^{2}\right)$ & Young, Dense & $5.4-15.6$ & 14 & 0.002 & 1.548 & - & 0.91 & 0.4 \\
\hline & - & Young, Sparse & $11.7-25.0$ & 15 & 0.004 & 1.497 & - & 0.76 & 67.9 \\
\hline & $\begin{array}{l}\text { Basal Area }\left(\mathrm{cm}^{2}\right), \\
\text { Crown Length }(\mathrm{m})\end{array}$ & 2 Young Stands & $5.4-25.0$ & 29 & 0.001 & 1.855 & -0.291 & 0.88 & 34.6 \\
\hline & - & 2 Sparse Stands & $11.3-33.3$ & 32 & 0.042 & 0.528 & 1.288 & 0.54 & 96.2 \\
\hline \multirow[t]{6}{*}{ Fine Fuels } & $\begin{array}{c}\text { Basal Area }\left(\mathrm{cm}^{2}\right), \\
\text { Sapwood Area }\left(\mathrm{cm}^{2}\right)\end{array}$ & All Sites & $5.4-33.3$ & 46 & 0.418 & 0.466 & 0.418 & 0.68 & 184.8 \\
\hline & - & Old, Sparse & $11.3-33.3$ & 17 & 0.524 & 0.323 & 0.403 & 0.81 & 58.3 \\
\hline & Basal Area $\left(\mathrm{cm}^{2}\right)$ & Young, Dense & $5.4-15.6$ & 14 & 0.002 & 1.695 & - & 0.96 & 1.4 \\
\hline & - & Young, Sparse & $11.7-25.0$ & 15 & 0.011 & 1.427 & - & 0.86 & 97.1 \\
\hline & - & 2 Young Stands & $5.4-25.0$ & 29 & 0.007 & 1.512 & - & 0.93 & 48.7 \\
\hline & Sapwood Area $\left(\mathrm{cm}^{2}\right)$ & 2 Sparse Stands & $11.3-33.3$ & 32 & 1.204 & 0.638 & - & 0.52 & 220.9 \\
\hline \multirow[t]{6}{*}{ Needles } & $\begin{array}{l}\text { Basal Area }\left(\mathrm{cm}^{2}\right), \\
\text { Sapwood Area }\left(\mathrm{cm}^{2}\right)\end{array}$ & All Sites & $5.4-33.3$ & 46 & 0.192 & 0.525 & 0.317 & 0.73 & 67.0 \\
\hline & Septor & Old, Sparse & $11.3-33.3$ & 17 & 0.249 & 0.323 & 0.471 & 0.82 & 33.0 \\
\hline & Basal Area $\left(\mathrm{cm}^{2}\right)$ & Young, Dense & $5.4-15.6$ & 14 & 0.002 & 1.600 & - & 0.91 & 1.5 \\
\hline & - & Young, Sparse & $11.7-25.0$ & 15 & 0.014 & 1.312 & - & 0.78 & 60.3 \\
\hline & - & 2 Young Stands & $5.4-25.0$ & 29 & 0.007 & 1.426 & - & 0.89 & 30.7 \\
\hline & Sapwood Area $\left(\mathrm{cm}^{2}\right)$ & 2 Sparse Stands & $11.3-33.3$ & 32 & 0.563 & 0.701 & - & 0.61 & 78.5 \\
\hline Tree Bole & Volume** & Old, Sparse & $11.3-33.3$ & 17 & 0.002 & 0.822 & - & 0.93 & 608.5 \\
\hline \multicolumn{10}{|c|}{ ( Linear Models, $y=a x+b)$} \\
\hline (Y) & $(\mathrm{X})$ & $\operatorname{Site}(\mathrm{s})$ & $\begin{array}{l}\text { DBH range } \\
(\mathrm{cm})\end{array}$ & $n$ & $a$ & $b$ & $c$ & $r^{2}$ & SE \\
\hline \multirow[t]{5}{*}{ Tree Bole } & Volume** & All Sites & $5.4-33.3$ & 46 & 0.0002 & 3.420 & - & 0.96 & 17.9 \\
\hline & - & Young, Dense & $5.4-15.6$ & 14 & 0.0002 & -0.327 & - & 0.79 & 8.9 \\
\hline & & Young, Sparse & $11.7-25.0$ & 15 & 0.0002 & 0.055 & - & 0.95 & 7.6 \\
\hline & - & 2 Young Stands & $5.4-25.0$ & 29 & 0.0002 & 5.482 & - & 0.93 & 8.9 \\
\hline & - & 2 Sparse Stands & $11.3-33.3$ & 32 & 0.0002 & 1.921 & - & 0.95 & 20.8 \\
\hline
\end{tabular}

Table 1. Allometric equations for predicting biomass $(\mathrm{Kg})$ of eight different above and belowground components of $P$. contorta in the Greater Yellowstone Ecosystem. Non-linear power functions are listed first, and linear equations are at the end of the table. MSE is the mean square error for non-linear models, SE is the standard error of the estimate for linear models, $n$ is the sample size, and $a, b$, and $c$ are constants. $\mathrm{X}$ is the morphometric predictor variable and $\mathrm{Y}$ represents the response variable (biomass $(\mathrm{Kg})$. The subscript ${ }_{2}$ is for predictors that are associated with the coefficient $c$ in non-linear models. $* *$ Volume is the product of basal area in $\mathrm{cm}^{2}$ and height in meters. 


\section{$\downarrow \quad$ RESULTS}

\section{ALLOMETRIC EQUATION DEVELOPMENT}

\section{Equation summaries}

Forty-eight allometric equations for all measured tree components are shown in Table $1 . \mathrm{R}^{2}$ values ranged from 0.54 to 0.99 , and 37 out of the 48 models had $\mathrm{R}^{2}$ values $>0.80$. For many of the measured tree components, equation strength decreased with increases in tree size, indicating greater variability in the biomass of larger trees. No single independent variable worked best for all allometric equations. Tree volume was the best predictor of both total aboveground biomass and bole biomass, regardless of stand density or age.

The most robust allometric equations were those that predict total aboveground, bole, total coarse root, and lateral root biomass; 23 of 24 of these equations had $\mathrm{R}^{2}$ values $>0.89$. In contrast, the remaining 24 equations, which predict root crown, branch, fine fuel, and needle biomass, were somewhat less robust; 13 of these equations have $\mathrm{R}^{2}$ values between 0.80 and 0.89 , and 9 equations have $\mathrm{R}^{2}$ values $<0.80$.

For many of the tree biomass compartments, including total aboveground biomass, bole biomass, branch biomass, and all root biomass compartments, a single equation that combined morphometry data from all three sites was more robust than equations that aggregated the sites by density or age. However, in general, when aggregated, grouping the sites by tree age produced stronger equations than aggregating by tree density (Table 1).

\section{Equation Comparisons between Stand Densities and Stand Ages}

For the 10 equations where statistical comparisons were possible, seven of the 10 equations tested differed significantly $(p<0.05)$ when aggregated by stand density or age. Interestingly, although the equations for root crown and lateral root biomass differed significantly when aggregated by stand age, no significant differences were found in equations aggregated by stand density. In addition, equations for total aboveground biomass were slightly more similar when aggregated by density ( $p$ $=0.037)$ than by age $(p<0.001)$.

\section{DISCUSSION}

\section{Allometric equation development}

Variation in stand density and age affected which of several measured tree morphometric parameters would best predict biomass of lodgepole pine tree components. The product of tree basal area and total height (volume) was the best predictor of total aboveground and bole biomass (Table 1). Notably, a tree's ability to produce stemwood biomass, a major component of tree bole and total aboveground biomass, is strongly influenced by site productivity (Barnes et al. 1980). Therefore, a model including tree height, a variable relating more strongly to site productivity than any other measured parameter (Barnes et al. 1980), can explain a large amount of the variability in bole and total aboveground biomass.

Total coarse root biomass $(>10 \mathrm{~mm})$, root crown biomass, and lateral root biomass are best explained by tree basal area (Table 1), where tree diameter and basal area are measured parameters most closely correlating with spacing effects related to tree density (Barnes et al. 1980), suggesting coarse root biomass is at least partly dependent on tree spacing.

Most of the variability in needle and foliage biomass is explained by basal area and sapwood area (Table 1). Sapwood area has been found to be a good predictor of foliage biomass in other studies (Pearson et al. 1984; Comeau and Kimmins 1989), because it is a good measure of a tree's ability to conduct water and nutrients. Needle and foliage biomass in the older stand was best explained either by sapwood area or a combination of sapwood and basal area (Table 1). In contrast, basal area was the single best predictor of foliage biomass in younger stands (Table 1), indicating that foliage biomass in younger forests is better explained by tree spacing rather than by the tree's ability to conduct water and nutrients.

\section{Differences between densities and ages}

Allometric models were expected to differ between densities and ages due to differences in biomass allocation patterns. For the most part, this was supported by the data. However, models for tree bole, root crown, and lateral roots did not differ when pooled by density, and models for aboveground biomass were less different when pooled by density than by age. One plausible explanation for this pattern is that stand densities may not have been different enough for some of the models to differ according to stand density or to be less different than for models pooled by age. Although 2,452 trees ha ${ }^{-1}$ 
was considered in this study to be a dense stand, "dog-hair" stands of lodgepole pine that are of comparable age can sometimes reach densities higher than 10,000 trees $\mathrm{ha}^{-1}$. Therefore, the relatively small difference in stand densities in this study may contribute to the relative similarity of models pooled by density compared with models pooled by age. Although allometric equations appear to be more similar across densities, application of models significantly different in density from where they were developed should be approached with caution. Furthermore, inappropriate model use can cause significant errors when extrapolating allometric equations to the landscape scale.

\section{ACKNOWLEDGEMENTS}

This research was supported by grants from the University of Wyoming - National Park Service competitive grants program, the Joint Fire Sciences Program, and from the Andrew W. Mellon Foundation.

\section{$\downarrow$ Literature Cited}

Barnes, B.V., D.R. Zak, S. R. Denton and S. H. Spurr 1980. Forest Ecology. New York, NY, John Wiley \& Sons, Inc.

Bates, D.M. and D.G. Watts 1988. Biometrics: nonlinear regression and its applications. New York, NY, John Wiley \& Sons.

Brown, J.K. 1978. Weight and density of crowns of Rocky Mountain conifers. Res. Pap. Int-197. Ogden, UT: U.S. Department of Agriculture, Forest Service, Intermountain Research Station; $56 \mathrm{p}$.

Comeau, P.G. and J.P. Kimmins 1989. Above- and below-ground biomass and production of lodgepole pine on sites with differing soil moisture regimes. Can. J. For. Res. 19: 447454.
Despain, D.G. 1990. Yellowstone vegetation: consequences and environment in a natural setting. Boulder, CO, Roberts Rinehart, Inc.

Gholz, H.L., C.C. Grier, A.G. Campbell and A. T. Brown. 1979. Equations for estimating biomass and leaf area of plants in the Pacific Northwest. Research Paper, Forest Research Laboratory, Oregon State University. 41: $39 \mathrm{pp}$.

Johnstone, W.D. 1971. Total standing crop and tree component distributions in three stands of 100-year-old lodgepole pine. Forest biomass studies. H. E. Young. Orono, ME, University of Maine Press. 15th IUFRO Congress: 81-89.

Kashian, D.M., M.G. Turner and W. H. Romme 2005. Variability in leaf area and stemwood increment along a 300-year lodgepole pine chronosequence. Ecosystems 8: 48-61.

Litton, C.M., M.G. Ryan, D. B. Tinker and D. H. Knight. 2003. Belowground and aboveground biomass in young postfire lodgepole pine forests of contrasting tree density. Can. J. For. Res. 33: 351-363.

Pearson, J.A., T. J. Fahey and D. H. Knight 1984. Biomass and leaf area in contrasting lodgepole pine forests. Can. J. For. Res. 14: 259-265.

Turner, M.G., D.B. Tinker, W. H. Romme, D. M. Kashian and C. M. Litton. 2004. Landscape patterns of sapling density, leaf area, and aboveground net primary production in postfire lodgepole pine forests, Yellowstone National Park (USA). Ecosystems 7: 751775. 